\title{
Glacial indicator dispersal processes: a conceptual model
}

\author{
PHILLIP C. LARSON AND HOWARD D. MOOERS
}

\section{BOREAS}

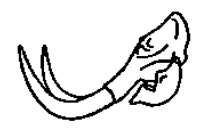

\begin{abstract}
Larson, P. C. \& Mooers, H. D. 2004 (August): Glacial indicator dispersal processes: a conceptual model. Boreas, Vol. 33, pp. 238-249. Oslo. ISSN 0300-9483.

Interpretation of indicator dispersal trains preserved in till sheets is widely used to investigate past glacial processes and to explore for buried bedrock mineralization. We present a conceptual model of erosion and entrainment and transport of indicator material in a glacial system. Indicator concentration in an individual size fraction of till is controlled by dilution and comminution. Dilution is the result of incorporation of additional material to the glacier's debris load down-ice of the indicator source, and is described in terms of erosivity and erosion length scale. Erosivity describes the amount of bed material eroded along a flowline, and is a function of both bed properties and the erosive power of the glacier. Erosion length scale describes the persistence of an indicator dispersal signal during transport, and controls both the maximum total indicator concentration and the eventual length of apparent dispersal. We adapt a modified batch grinding particle comminution model to describe breakdown of indicator material during transport and modification of the indicator particle size distribution. Indicator dispersal concentrations are the product of dilution and comminution processes.
\end{abstract}

Phillip C. Larson (e-mail: plarson2@d.umn.edu) and Howard D. Mooers, Department of Geological Sciences, University of Minnesota, Duluth, MN 55812, USA; received 20th October 2003, accepted 16th January 2004.

Indicators are till components with a unique lithologic, mineralogic or geochemical signature that are eroded by a glacier from a known source (Shilts 1993). Glacial dispersal is erosion of a bedrock component and entrainment and transport by the action of glacial ice to a site of deposition. The area over which indicator material is dispersed is the 'dispersal train' (Shilts 1982). Dispersal trains are commonly characterized by an exponential decrease in indicator concentration of till with transport length from the source (Shilts 1982). (We prefer to use the term transport length (units of distance) instead of the more commonly used transport distance, recognizing that, in comparison to the other particles comprising a till sheet, a particle that has been transported a longer distance has generally been in transport a longer period of time.)

Indicator dispersal tracing has historically been one of the principal approaches to investigation of till sedimentology. Indicator dispersal trains have been used to investigate a wide variety of glacial processes, including debris transport and glacial flow paths (Milthers 1909; Sauramo 1929; Repo 1957; Flint 1971; Prest \& Nielsen 1987). Today, indicator dispersal tracing methods are widely used by the mineral exploration industry to explore for bedrock mineralization concealed by overburden in glaciated landscapes (Kujansuu \& Saarnisto 1990; Shilts 1993; McClenaghan et al. 2000; McClenaghan et al. 2001).

Despite much previous work on indicator dispersal tracing and its wide application, the mechanisms controlling indicator dispersal are poorly understood relative to other glacial processes. To the first order, indicator dispersal patterns are a function of the processes of dilution and comminution acting on that indicator during transport. Dilution reduces indicator concentration by eroding and incorporating material from the bed, while comminution affects the particle size distribution of the indicator and thus its concentration in a particular size fraction. However, there is a lack of specific data relating the relative changes in indicator concentrations due to dilution (chiefly a function of interaction with the bed) and comminution (chiefly a function of the material properties of the indicator). This has precluded satisfactory quantitative modelling of glacial debris transport. Increasing our understanding of the processes that control indicator dispersal during glacial transport and the rates at which these processes act is contingent on distinguishing the effects of dilution and comminution on indicator concentration.

We present a conceptual model of the processes of indicator erosion and entrainment and transport. We also propose adaptation of a batch-grinding particle comminution model (Horst \& Freeh 1970) to quantification of indicator debris modification during transport in glacial systems. Finally, we link our erosionentrainment and comminution models to describe indicator dispersal concentrations in individual size fractions.

\section{Controls on spatial distribution of indicators in till}

The position of any given particle comprising a till sheet (including an indicator) is the product of four processes: erosion, entrainment, transport, and deposition. Erosion in the strictest sense is mechanical detachment of particles from the bed. Entrainment is the process whereby particles are incorporated into the glacier's 
debris load. Transport moves particles from the site of erosion and entrainment to some down-ice point on the flowline. Deposition occurs when the glacier ceases to transport a particle.

A number of models have been proposed to explain each process. Erosion might occur by quarrying or abrasion (Sugden \& John 1976; Drewry 1986). Entrainment might occur by freeze-on to basal ice and incorporation into glacial ice (Weertman 1961; Robin 1976; Knight 1997). Alternately, erosion and entrainment might occur by mobilization of unconsolidated sediment or weak bedrock into a deforming subglacial layer (Boulton 1996). Transport may occur at a number of positions with respect to the bed, and during periods of net entrainment or deposition. Deposition may occur by lodgement (Dreimanis 1989) or meltout (Drewry 1986). The nature and relative importance of the processes may vary from till sheet to till sheet, or spatially and temporally during generation of a single till sheet. The concentration and particle size distribution of an indicator at any location in a till sheet is the product of a unique combination of erosion and entrainment rates, transport pathways, and deposition rates.

The distribution of an indicator lithology in a till sheet - the dispersal train of common usage - has commonly been envisioned as recording steady-state erosion, transport, and deposition processes acting over an indeterminate time period. We suggest that the dispersal train is best viewed as an aggregate of individual particle trajectories, potentially recording spatial and temporal variations in rates of erosion, entrainment, depositional processes, and directions and rates of transport. Viewed in this framework, the extent to which field data outline an indicator dispersal train defined by an exponential decay profile (Gillberg 1965), or any other dispersal model, merely reflects the extent to which processes implicitly incorporated into the model adequately capture the complexity of, and variation in, processes acting in the glacial system.

Interpreting till composition: mass balance vs. indicator concentration

Ideally, one would use a mass balance as the basis for describing and quantifying debris transport and deposition in a glacier and its distribution in a resulting till sheet. Assuming basal debris transport in a glacial system is essentially laminar in the sense that lateral dispersion is minimal, and the mean specific gravity of the entrained debris does not change, continuity requires that:

$$
\frac{\partial m}{d t}=e-\frac{\partial\left(m_{d} \bar{u}\right)}{\partial T}
$$

where $e$ is the net erosion rate (mass $\cdot$ length $^{-2} \cdot$ time $^{-1}$ ), $t$ is time, $T$ is flowline transport length, $\bar{u}$ is the mean downglacier velocity of the debris layer, and $m$ is the entrained debris mass per unit basal area (mass $\cdot$ length $^{-2}$ ). Application of Equation (1) to interpretation of indicator concentration distribution in a till sheet requires that four parameters are known. The flowline length is easily determined and the mean velocity can be estimated to within an order of magnitude. However, the erosion rate is not known $a$ priori. Similarly, control of the mass of debris per unit basal area, $m$, at every $T$ is poor, since the surface of a till sheet is typically exposed to erosion, either subaerially or by subsequent glaciations. Field study of tills alone provides insufficient data to quantify glacial debris transport processes using a mass balance approach.

An alternative approach to quantification of glacial debris transport is interpretation of indicator concentrations preserved in the resulting till sheet. While physical partitioning of indicator material into a range of particle sizes during erosion and transport complicates interpretation, examination of indicator concentrations has the advantage that they are preserved in till regardless of the amount of post-depositional erosion the till sheet may have undergone.

\section{Total indicator concentration}

Consider a section through a glacier oriented parallel to a flowline of unit width (Fig. 1A). The bed contains a subcrop of indicator lithology with a flowline dimension of $L$. Define a coordinate system where $T$ is the flowline transport length in the down-ice direction from the down-ice boundary of the indicator subcrop.

At $T=-L$ the glacier transports a given debris mass per unit bed area, $m$. This debris is the sum of material eroded and entrained in the area $T<-L$. The debris mass incorporated into the glacial debris load is dependent on the mass eroded and entrained per unit bed area per unit flowline length, or erosivity $E$ (mass $\cdot$ length $^{-3}$ ).

Erosivity is a function of the strength of the erosionentrainment interaction between the glacier's bed and the overriding ice; it is a function both of the mechanical strength of the bed and the ability of the glacier to exert force on, and entrain material from, the bed. Over any flowline interval $T$, erosivity is related to an absolute erosion rate $e$ (length $\cdot$ time $^{-1}$ ) by:

$$
e=\frac{E u}{\rho_{b}},
$$

where $u$ is the mean velocity of the glacial debris load, and $\rho_{\mathrm{b}}$ is the specific gravity of the bed.

It is convenient to recast $E$ as an erosion length scale $\lambda$ (length):

$$
\lambda=\frac{m}{E}
$$

The erosion length scale describes the influence of 
A
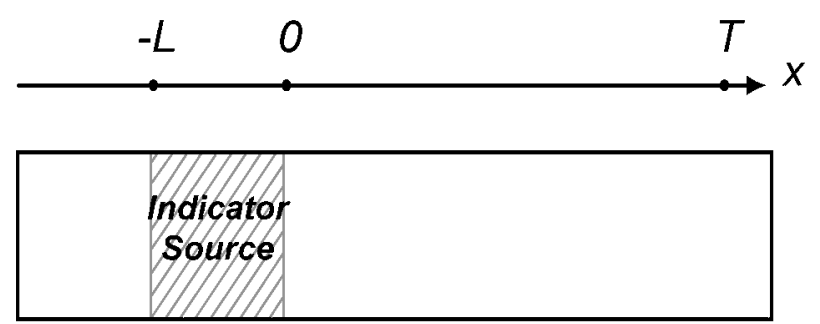

B

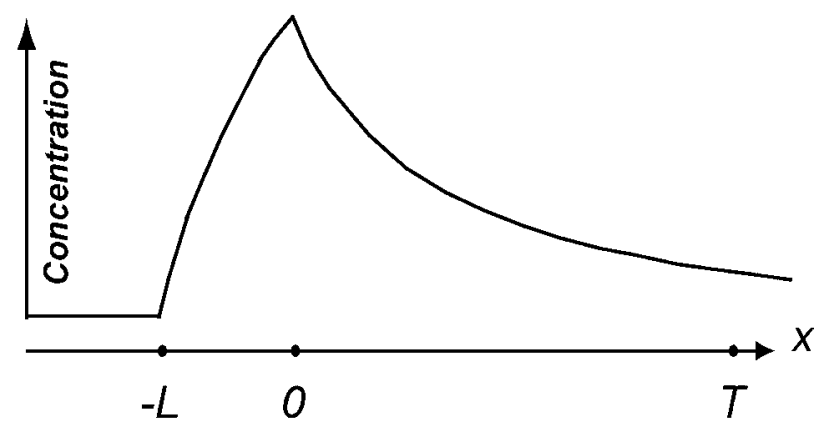

Fig. 1. Schematic of dispersal model showing (A) the model domain and (B) the concentration of indicator material as a function of transport length. $T$ is any arbitrary transport length down-ice of the down-ice edge indicator source. $-L$ is the transport length to the upice edge of the indicator source corresponding to a flowline length of the indicator outcrop, $L$.

debris derived up-ice of the indicator source on the generation of the indicator dispersal train.

Over the flowline interval $-L<T<0$, the glacier erodes and entrains indicator debris. Assuming a spatially uniform erosivity $E$, indicator mass $m_{i}$ added to the debris load is:

$$
m_{i}=E \cdot L .
$$

Assuming eroded and entrained material is instantly mixed throughout the debris load, the mass fraction of indicator debris in the debris load at $T=0$ is:

$$
c_{i}^{T=0}=\left(\frac{m_{i}}{m_{i}+m}\right)
$$

For flowline intervals $T>0$, erosion and entrainment of non-indicator debris occurs. Assuming continued spatially uniform bed erosivity $E$, the additional material incorporated into the debris load is:

$$
m^{T>0}=E \cdot T
$$

Incorporating Equation (6) into Equation (5) and normalizing with respect to the uniform erosivity $E$ results in the mass fraction of indicator lithology in the debris load for $T>0$ of:

$$
c_{i}^{T \geq 0}=c_{D I L}=\left(\frac{L}{L+\lambda+T}\right) .
$$

We refer to the indicator mass fraction described by Equation (7) as the dilution concentration $c_{D I L}$ in as much as it is solely a function of addition of material by erosion and entrainment. Figure 1B illustrates a hypothetical indicator concentration profile oriented parallel to a flowline.

\section{Indicator comminution}

Consider all indicator material eroded and incorporated into the glacial debris load at $T=0$. The indicator material has a particle size distribution $X$ controlled by the fracture density, mechanical strength, and outcrop geometry of the indicator material. In addition, the particle size distribution is influenced by the nature of erosion and entrainment processes acting at the indicator source. During transport, indicator particles are subject to applied forces that may result in comminution and modification of this particle size distribution.

Glacial comminution during transport is analogous to a batch-grinding model of particle comminution (Horst \& Freeh 1970), wherein an initial charge of material (the indicator) with particle size distribution $X$ is comminuted in a mill (the glacier) for a certain length of time (or transport length). Applying this framework to a glacial system, the fraction of indicator mass $x$ in a size range $i$ may be obtained by a simple mass balance:

$$
\frac{\mathrm{d} x_{i}}{\mathrm{~d} T}=-\mathrm{k}_{i} \mathrm{x}_{i}+\sum_{j=1}^{i=1} a_{i j} \mathrm{k}_{j} x_{j}
$$

where the $k$ values are first-order breakage rate coefficients, and the elements $a_{i j}$ are size distribution coefficients. The breakage rate coefficients $k$ describe the comminution rate ( $k=0$ in the case of no comminution during transport). The size distribution coefficients $a_{i j}$ describe the particle size distribution of comminution daughter products.

The process of comminution is thus described in terms of the indicator particle size distribution as a function of transport length. Figure 2B illustrates a hypothetical pattern of evolution of the particle size distribution for a three-component system. The model with only three size fractions is simple; however, it incorporates the main features of indicator comminution during transport: a depleting reservoir of coarse particles, an accumulating reservoir of fine particles, and transitory fraction of the indicator mass in the intermediate size fraction. The hypothetical indicator concentration patterns in Fig. 2C illustrate an indicator dispersal pattern in which the initial debris load is quite 
coarsely skewed, resulting in an apparent increase in indicator concentration in small to intermediate size fractions down-ice of the indicator source. Erosion of a higher proportion of fines than illustrated from the
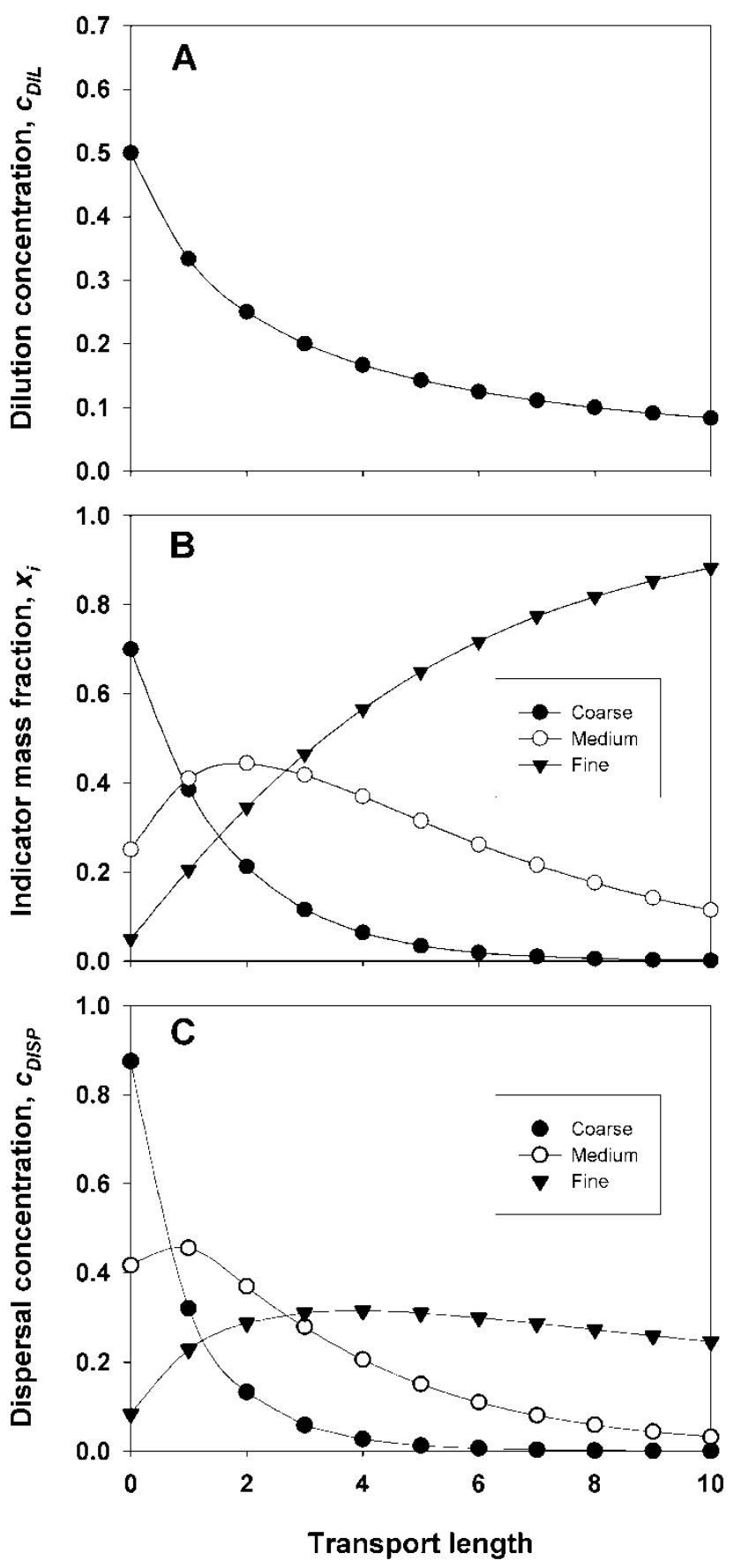

Fig. 2. Hypothetical indicator dispersal parameters. A. Concentration of indicator as a proportion of total till mass; B. Proportion of indicator mass in various size fractions $\left(x_{i}\right)$; C. Dispersal concentration of indicator in individual size fractions. A constant till particle size distribution is assumed (mass fractions: 0.4 coarse, 0.3 medium, and 0.3 fine). Units of transport length are arbitrary. indicator outcrop results in an apparent decrease in indicator concentration in all size fractions (cf. Shilts 1993: fig. 8).

\section{Indicator dispersal concentration}

We have presented models describing the effects of dilution on total indicator concentration and of comminution on indicator particle size distribution. However, indicator concentration in a till in a particular size fraction at a particular location is a function of the effects of both comminution and dilution processes. Neither Equation (7) nor (8) completely describes indicator concentration during glacial transport.

We define the concentration of an indicator in a particular size fraction of till as the dispersal concentration $c_{D I S P}$ in as much as this is the value measured in essentially all indicator dispersal studies. The dispersal concentration over the flowline interval $T>0$ is a function of both the total indicator concentration and the net effects of comminution on the proportion of indicator material present in that particular size fraction. Dispersal concentration for particle size fraction $i$ at a particular transport length $T$ is related to the dilution concentration and indicator particle size distribution by:

$$
c_{D I S P}=\frac{c_{D I L} x_{i}}{x_{\text {till }}}
$$

where $x_{\text {till }}$ is the fraction of till mass in particle size fraction $i$. Figure 2C illustrates a hypothetical set of indicator dispersal patterns for three size fractions corresponding to hypothetical dilution and comminution scenarios presented in Fig. 2A and B.

It is important to recognize that for the vast majority of indicator dispersal studies, while physical partitioning distributes indicator material into a broad range of particle sizes, concentrations are measured in only a limited range of particle sizes. It is often technically infeasible to collect samples of sufficient size to characterize indicator concentration in the coarsest size fractions. Except by geochemical means, it may be impossible to distinguish indicator from background material in the finest size fractions. Most indicator dispersal studies are therefore measuring the dispersal concentration $c_{D I S P}$, rather than the total indicator concentration $c_{D I L}$.

Plotting dispersal concentration $c_{D I S P}$ as a function of transport length $(T)$ from the indicator source produces a dispersal curve analogous to the numerous dispersal curves described in the literature (see Shilts 1976; Kujansuu \& Saarnisto 1990; Shilts 1993; McClenaghan et al. 2001, among others).

\section{Discussion}

The conceptual models presented above provide a 
framework for quantitative investigation of glacial indicator dispersal processes. It is not the intention of this article to provide an exhaustive review of all possible permutations of indicator dispersal patterns. However, consideration of the equations describing indicator concentration reveals a number of phenomena with immediate bearing on interpretation of field data.

\section{Exponential decay relationship}

The total indicator concentration-transport length relationship presented in Equation (7) indicates that given uniform bed erosivity and long-term steady-state conditions, the total indicator concentration $c_{D I L}$ distribution in a till sheet should assume a particular form. Over transport lengths greater than the flowline length of the indicator outcrop $L$, the decrease in total indicator concentration $c_{D I L}$ (Fig. 2A) is closely approximated by an exponential decay function, a conclusion empirically reached by many workers (e.g. Gillberg 1965; Shilts 1976; Pertunnen 1977). The decrease is not described exactly by an exponential decay function due to a constant rate of debris incorporation down-ice of the indicator outcrop, governed by a constant erosivity $E$.

In a similar fashion, in cases where the change in particle size $d x_{i} / d T$ in an individual size fraction $i$ is negative (Eqn. 8), the decreasing indicator mass fraction in size fraction $i$ is closely approximated by an exponential decay function. In the case of the largest size fraction, in which indicator mass fraction is solely dependent on a constant rate of depletion of a finite particle reservoir, $d x_{i} / d T$ is exactly described by an exponential decay function. Thus, both dilution and comminution processes tend to impart a quasi-exponential form to decrease in indicator dispersal concentrations and the indicator dispersal train. Dilution by incorporation of down-ice debris strongly imparts a quasi-exponential form to the indicator dispersal trains, implying that in many cases comminution may play a significantly lesser role in controlling the indicator dispersal concentration for a particular size fraction.

Exponential uptake and decay functions have been used to describe both indicator erosion and entrainment, and dilution of indicator concentration during transport (Klassen 2001). The Klassen (2001) model describes erosion and entrainment of indicator material into the glacial debris load over the indicator source (flowline interval $T=-L$ to 0 ), and the resulting increasing indicator concentration in till by:

$$
c_{i}^{L>0}=c_{a}\left(1-e^{-a L}\right),
$$

where $c_{a}$ is a 'practical' maximum indicator concentration, and $a$ is a dimensionless constant. Assuming that incorporated indicator debris is instantly mixed into the glacial debris load, maximum indicator concentration $c_{i}$ is reached at the down-ice boundary of the indicator outcrop $(T=0)$.
Klassen (2001) describes erosion and entrainment of 'background' material down-ice of the indicator outcrop (flowline interval $T>0$ ) and consequent dilution of indicator concentration by:

$$
c_{i}^{T>0}=c_{i}^{T=0} e^{-a T},
$$

where $a$ is dimensionless constant.

The dimensionless constants $a$ in Equations (10) and (11) incorporate the entirety of physical variables that may influence erosion and entrainment of substrate material. Assuming that erosion and entrainment of background and indicator material occur at the same rate, $a$ in Equations (10) and (11) are equivalent.

Figure 4 is a plot of hypothetical total indicator concentrations predicted by our model (Eqn. 7) and the Klassen (2001) model (Eqns. 10 and 11). In both cases, erosion and entrainment rates of indicator and down-ice background debris are assumed to be equal, and an identical maximum total indicator concentration is reached at $T=0$. Both models predict essentially similar rates of indicator uptake over the source. Both models also predict an exponential (Klassen 2001) or essentially exponential (this study) decay in indicator concentration down-ice of the source. However, our model predicts a significantly lower rate of decrease in total indicator concentration with transport length, resulting in the indicator being distinguishable from background over significantly greater transport lengths. In this respect, we believe our model is able to more satisfactorily reproduce the empirical observation that the areal extent of an indicator dispersal train is typically many times larger than that of its source (Shilts 1993; McClenaghan et al. 2000).

\section{Erosion length scale}

Equations (3) and (7) indicate that the maximum magnitude of indicator concentration in a dispersal train, and the maximum transport length at which it is resolvable from background, is strongly dependent on the erosion length scale, $\lambda$.

In the case where $\lambda$ is relatively low, till composition strongly reflects that of the nearby underlying bed, and the mean distance material is apparently transported is relatively short. Equation (3) indicates this is characteristic of a thin basal debris layer and/or high erosivity. In this case, the glacier is able to incorporate indicator material at a relatively high rate, resulting in a rapid increase to a relatively high indicator concentration value over the source. However, down-ice from the indicator source the indicator concentration rapidly decreases. The result is an indicator dispersal pattern characterized by short apparent mean particle transport lengths (cf. Pertunnen 1977), and approximately described by an exponential decay function (Gillberg 1965; Shilts 1976; Pertunnen 1977; Peltoniemi 1985) (Fig. 3A). 
A

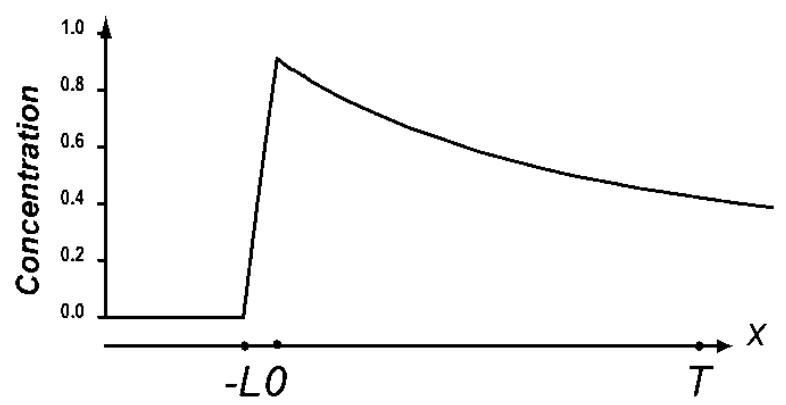

B

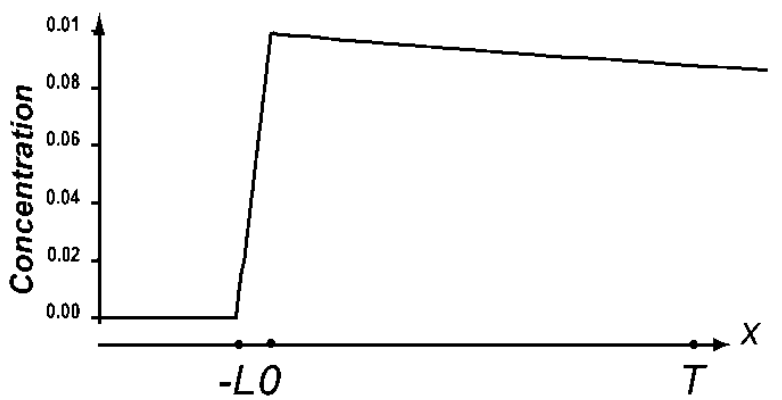

Fig. 3. Indicator concentration along flowline parallel transects; variation is a function of erosion length scale. A. Arbitrary erosion length scale $\lambda$. B. erosion length scale $10 \lambda$. Note that the maximum indicator concentration in $(\mathrm{A})$ is $\sim 10 \mathrm{x}$ that of $(\mathrm{B})$.

In the case where $\lambda$ is high, the till composition largely does not reflect that of the underlying bed, and material is apparently transported for relatively long distances. Equation (3) indicates this is characteristic of a thick basal debris layer and/or low erosivity. In this

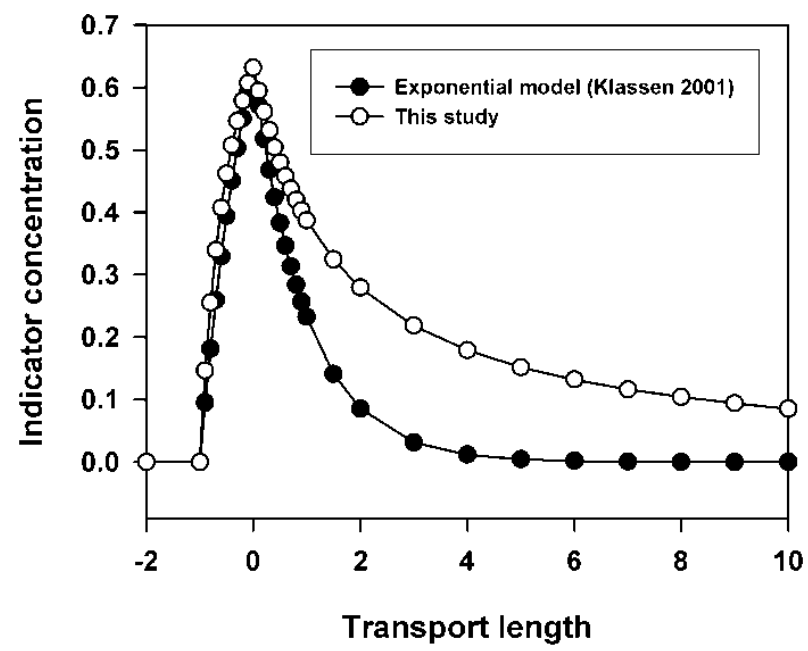

Fig. 4. Total indicator concentrations derived from exponential model of indicator erosion and transport (Klassen 2001) and the model presented in this study. case, the glacier incorporates a relatively small amount of indicator material resulting in low magnitude indicator concentration. However, the indicator dispersal train persists for long transport lengths. The result is an indicator dispersal pattern characterized by a very low rate of down-ice decrease in concentration, often approximately described by a linear decay function (cf. Shilts 1993; Klassen 2001) (Fig. 3B).

It has been suggested that this dispersal pattern is characteristic of tills formed by deposition from deforming subglacial layers (Klassen 2001). The concentration of shale clasts derived from Cretaceous rocks in southern Manitoba in Des Moines lobe till of the Minnesota River Valley shows virtually no decrease along the axis of the lobe (Matsch 1972); this till is interpreted to have been formed by a deforming bed (Alley 1991; Clark 1994). Similarly, Thorleifson \& Kristjansson (1993) found virtually no decrease in carbonate and greywacke clasts derived from the Hudson Bay Lowland in tills along a flowline-parallel transect north of Lake Superior; these tills are also interpreted to have been formed by a deforming bed (Hicock \& Dreimanis 1992).

The inferred association of deformable bed tills and high erosion length scales suggests deforming beds are only able to erode their substrate at extremely low rates if at all. This conclusion is inconsistent with most deforming bed models, which conjecture that subglacial deforming beds are able to maintain flux continuity by erosion of substrate and incorporation into the deforming layer (Boulton 1996; Alley et al. 1997). It likewise suggests that refinement of current deforming bed models and reassessment of the conjectured widespread occurrence in ancient and modern glacial environments is necessary, as suggested by Piotrowski et al. (2001) and Hooyer \& Iverson (2002).

\section{Comminution}

The overall tendency of the textural evolution of indicator material during transport is for coarser clasts to break down to finer clasts. Calculation of the relative values of $x_{i}$ for all indicator size fractions quantifies the changing indicator particle size distribution with transport length. The evolution of the particle size distribution with transport length is a function of the comminution processes acting on the debris and the mechanical strength of the debris itself.

\section{Change in comminution rates with transport length}

Equation (8) describes indicator comminution in terms of breakage rate coefficient $k$ and size distribution coefficients $a$. These constants may be expected to vary with transport length $T$ due to a number of factors.

The breakage rate coefficients $k$ describe the probability that a clast will be broken over a certain transport length. Early breakage during transport exploits flaws in 
the weakest clasts. Surface wear tends to increase the textural maturity of clasts resulting in residual particles strongly resistant to further wear by abrasion. With increasing transport length, the residual clasts and daughter particles of earlier breakage events will form a progressively more stable assemblage, leading to reduction in $k$ with transport length. These effects have been observed in a number of indicator dispersal studies (Holmes 1960; Drake 1972; Humlum 1985; Kjær 1999).

The size distribution coefficients $a_{i j}$ describe the mean particle size distribution of the daughter products of clast breakage events. In addition to the mechanical strength of the indicator material, the value of these coefficients is highly dependent on the comminution process active during particle breakdown (see Sharp \& Gomez 1986). Dominance by cleavage (crushing) tends to produce a monomodal size distribution with a range of particle sizes. Dominance by surface wear (abrasion) tends to produce a bimodal size distribution as abrasion removes small particles from the surfaces of larger clasts. In practice, both abrasion and crushing contribute to clast comminution, demonstrated both experimentally and using field data by Haldorsen (1981). However, increasing textural maturity during transport favors abrasion and the production of a bimodal daughter product distribution at the expense of crushing.

\section{Effects of comminution on indicator dispersal patterns}

The net rate of decrease of indicator material resident in size fraction $i$ is the difference between the rate at which comminution generates products of size fraction $i$ from larger sizes, and breaks down particles of size fraction $i$ to smaller sizes (Eqn. 8). The mass fraction of an indicator in a particular size fraction is thus strongly dependent on the size of the reservoir of coarser indicator particles in transport. Comminution of a reservoir of coarser particles will initially maintain, or may even increase, the mass fraction of indicator material present in a smaller size fraction. As the coarser reservoir is depleted, and comminution losses continue, the mass fraction $x_{i}$ decreases. The exception is the terminal grade (Dreimanis \& Vagners 1971). During transport, indicator material accumulates in the terminal size fraction $x^{\circ}$, and the mass fraction in this size fraction increases relative to indicator material in other size fractions $x_{i}$.

\section{Case study: glacial erosion over the Vermilion Greenstone Belt, Minnesota}

Indicator dispersal patterns in till overlying the Vermilion Greenstone Belt in northern Minnesota, United States, provide a convenient data set with which to demonstrate the utility of applying the conceptual model presented above to interpretation of subglacial processes, specifically the rates of glacial erosion and entrainment of bedrock material.

The Vermilion Moraine formed $c .12 \mathrm{ka}$ ago during the retreat of the Rainy Lobe of the Laurentide Ice Sheet (LIS) (Lehr \& Hobbs 1992; Fig. 5). North of the moraine, till occurs as a thin $(\sim 1 \mathrm{~m})$ veneer of basal lodgement and meltout tills mantling glacially scoured bedrock. The compositional similarity between recessional moraine and ground moraine tills, including continuity of indicator dispersal trends, indicates that both formed synchronously. The tills are generally sandy textured and contain angular coarse-grained clasts. Orientation of the Vermilion Moraine indicates a flow vector of $\sim 210^{\circ}$ during the period of till generation.

Bedrock in the study area consists of rocks of the Archean Superior Province (Peterson \& Jirsa 1999). The Vermilion Fault defines a major crustal boundary between the Quetico Subprovince to the north and the Wawa Subprovince to the south. Quetico Subprovince rocks consist of granitic intrusions and high-grade metasedimentary rocks (gneisses) of the Vermilion Granitic Complex (VGC), which is present up-ice along the flowline for $>100 \mathrm{~km}$. Wawa Subprovince rocks consist of greenschist-grade metavolcanic and metasedimentary rocks of the Vermilion Greenstone Belt (VGB).

Till samples averaging $8.5 \mathrm{~kg}$ of $<16 \mathrm{~mm}$ size material were collected from 4 sites overlying the VGC and 38 sites overlying the VGB. From these samples, an average of $3.3 \mathrm{~kg}$ of pebbles in the 2$16 \mathrm{~mm}$ size fraction were recovered and separated into the $2-4,4-8$, and $8-16 \mathrm{~mm}$ size fractions. The mass fraction of granitic clasts in each size fraction of each sample was determined by physically separating and weighing the granite and greenstone clasts in splits comprising at least 500 grains. Transport lengths for each sample location were calculated by measuring the distance to the Vermilion Fault along a bearing of $30^{\circ}$. These data are presented in Table 1.

Tills overlying the VGC immediately north of the Vermilion Fault are composed entirely of granitic material derived from the VGC and contain no greenstone. Any greenstone clasts found in till south of the Vermilion Fault, therefore, must have been eroded from the VGB, and have been transported only a few kilometers before deposition. Decreasing concentrations of granitic clasts in till south of the Vermilion Fault therefore serve as an indicator recording the progressive erosion and entrainment of greenstone into the glacial debris load (Fig. 6).

\section{Comminution of granitic clasts during transport}

The mean particle size of granitic clasts in the $2-16 \mathrm{~mm}$ till size fraction essentially does not change over nearly $12 \mathrm{~km}$ of transport (Fig. 7). Communition of granitic 


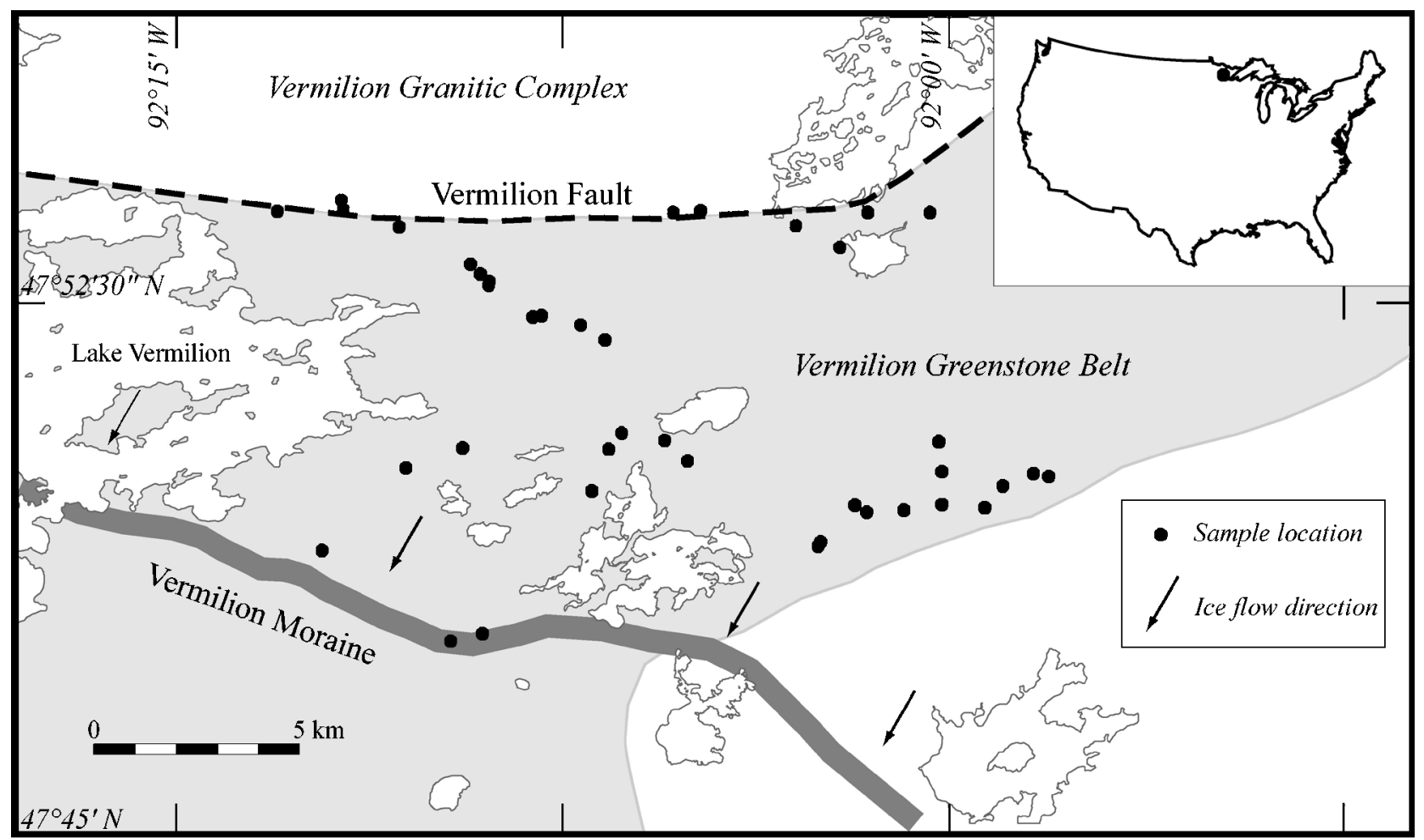

Fig. 5. Map of Vermilion Greenstone Belt showing till sample locations.

clasts during transport was apparently minimal, and therefore appears to have played only a small role in the decrease in granitic concentration in the analyzed size fractions.

\section{Erosivities}

Erosivities $E$ were calculated from Equation (4) assuming an initial glacial debris load $m$ of $1000 \mathrm{~kg} \cdot \mathrm{m}^{-2}$ at the Vermilion Fault (Table 1). The calculated erosivity values scale linearly with the value assumed for $m$, and have the potential to vary significantly depending on this initial assumption.

Calculated erosivities are significantly higher over the first $\sim 3 \mathrm{~km}$ of transport length south of the Vermilion Fault (Table 1 and Fig. 8). This may be the result of significantly higher rates of erosion and entrainment of greenstone material proximal to the Vermilion Fault, or may be an artifact of temporal variation in erosion and entrainment rates over the entire greenstone belt. Rocks immediately south of the Vermilion Fault are intensely deformed by shearing associated with the fault, and altered by carbonic fluids, both of which significantly decrease the mechanical strength and resistance to chemical weathering. As such, data from this study area alone are insufficient to distinguish between the two hypotheses.
Calculated erosivities for samples greater than $8 \mathrm{~km}$ transport length from the Vermilion Fault are probably a better record of longer-term mean erosion and entrainment rates over the greenstone belt. Assuming an initial $m$ of $1000 \mathrm{~kg} \cdot \mathrm{m}^{-2}$ at the Vermilion Fault, the mean erosivity over this interval is $0.825 \mathrm{~kg} \cdot \mathrm{m}^{-3}$. Following Equation (2), assuming the basal velocity, and correspondingly the debris load velocity, during the period of till generation was $50 \mathrm{~m} \cdot \mathrm{a}^{-1}$, and assuming a greenstone specific gravity of $3000 \mathrm{~kg} \cdot \mathrm{m}^{-3}$, a mean basal erosion rate of $13.8 \mathrm{~mm} \cdot \mathrm{a}^{-1}$ is indicated. This rate is comparable to that of modern large, temperate Alaskan glaciers (Hallet et al. 1996). Such a high rate of erosion and entrainment would clearly be unsustainable for a long period of time over a large area of the ice sheet's base. This suggests that erosion and entrainment by the LIS while it terminated at the Vermilion Moraine, while operating at high rates, was spatially and temporally restricted. This spatial and temporal restriction of significant erosion and entrainment is consistent with the Rainy Lobe having terminated at the Vermilion Moraine for 1000 years at most.

\section{Erosion length scale}

The erosion length scale $\lambda$ was derived from calculated erosivities using Equation (3). These values are in 
Table 1. Granitic indicator dispersal data for tills overlying the Vermilion Greenstone Belt. *Denotes samples with anomalously low or high granitic concentration with respect to transport length; these are excluded from calculation of erosivity and erosion length scale.

\begin{tabular}{|c|c|c|c|c|c|c|c|c|c|c|c|c|}
\hline \multirow{2}{*}{$\begin{array}{l}\text { Sample } \\
\text { no. }\end{array}$} & \multirow{2}{*}{$\begin{array}{l}\text { Transport } \\
\text { length }(\mathrm{m})\end{array}$} & \multicolumn{4}{|c|}{ Sample mass $(\mathrm{kg})$} & \multicolumn{4}{|c|}{ Granitic concentration (mass fraction) } & \multirow{2}{*}{$\begin{array}{l}\text { Mean granitic } \\
\text { grain size } \\
\text { (phi) }\end{array}$} & \multirow{2}{*}{$\begin{array}{l}\text { Erosivity } \\
\left(\mathrm{kg} \cdot \mathrm{m}^{-3}\right)\end{array}$} & \multirow{2}{*}{$\begin{array}{l}\text { Erosion } \\
\text { length } \\
\text { scale }(\mathrm{m})\end{array}$} \\
\hline & & Total & $+8 \mathrm{~mm}$ & $+4 \mathrm{~mm}$ & $+2 \mathrm{~mm}$ & $+8 \mathrm{~mm}$ & $+4 \mathrm{~mm}$ & $+2 \mathrm{~mm}$ & $2-16 \mathrm{~mm}$ & & & \\
\hline 5 & -342 & 7.241 & 0.413 & 0.508 & 0.611 & 1.000 & 1.000 & 1.000 & 1.000 & & & \\
\hline 51 & -253 & 8.716 & 0.563 & 0.545 & 0.550 & 1.000 & 1.000 & 1.000 & 1.000 & & & \\
\hline 52 & -234 & 8.690 & 0.446 & 0.593 & 0.748 & 1.000 & 1.000 & 0.997 & 0.999 & & & \\
\hline 6 & -121 & 6.451 & 0.945 & 0.973 & 1.058 & 0.983 & 1.000 & 1.000 & 0.994 & & & \\
\hline 7 & 75 & 9.343 & 1.463 & 1.398 & 1.231 & 0.378 & 0.278 & 0.266 & 0.310 & -2.79 & 29.674 & 34 \\
\hline 24 & 110 & 9.890 & 1.107 & 1.056 & 1.188 & 0.333 & 0.223 & 0.129 & 0.226 & -2.96 & 31.294 & 32 \\
\hline $8 *$ & 181 & 5.572 & 0.573 & 0.906 & 0.964 & 0.034 & 0.065 & 0.040 & 0.048 & -2.34 & & \\
\hline 25 & 265 & 8.307 & 0.997 & 1.259 & 1.124 & 0.301 & 0.338 & 0.226 & 0.290 & -2.55 & 9.265 & 108 \\
\hline 53 & 279 & 10.052 & 1.203 & 1.334 & 1.134 & 0.352 & 0.280 & 0.274 & 0.302 & -2.65 & 8.290 & 121 \\
\hline 54 & 889 & 8.372 & 0.907 & 0.913 & 0.900 & 0.305 & 0.245 & 0.211 & 0.254 & -2.69 & 3.313 & 302 \\
\hline 9 & 1003 & 6.939 & 0.354 & 0.559 & 0.729 & 0.529 & 0.526 & 0.541 & 0.533 & -2.15 & 0.873 & 1145 \\
\hline 23 & 1075 & 7.556 & 0.953 & 1.109 & 1.581 & 0.491 & 0.649 & 0.502 & 0.544 & -2.27 & 0.780 & 1282 \\
\hline 10 & 1265 & 6.564 & 1.178 & 0.949 & 0.741 & 0.322 & 0.495 & 0.454 & 0.413 & -2.55 & 1.123 & 891 \\
\hline 11 & 1452 & 10.495 & 0.644 & 0.749 & 0.884 & 0.790 & 0.735 & 0.148 & 0.523 & -2.84 & 0.629 & 1591 \\
\hline 12 & 1452 & 8.218 & 0.679 & 0.691 & 0.725 & 0.729 & 0.746 & 0.806 & 0.761 & -2.41 & 0.216 & 4620 \\
\hline 22 & 1551 & 9.354 & 1.141 & 1.267 & 1.416 & 0.461 & 0.442 & 0.460 & 0.454 & -2.39 & 0.774 & 1291 \\
\hline 20 & 2342 & 10.860 & 1.216 & 1.377 & 1.176 & 0.280 & 0.221 & 0.296 & 0.264 & -2.49 & 1.193 & 838 \\
\hline 21 & 2369 & 7.720 & 1.190 & 1.192 & 1.043 & 0.100 & 0.148 & 0.199 & 0.147 & -2.25 & 2.451 & 408 \\
\hline 19 & 2563 & 8.200 & 2.037 & 1.771 & 1.189 & 0.043 & 0.066 & 0.036 & 0.049 & -2.69 & 7.511 & 133 \\
\hline 18 & 2940 & 9.121 & 1.184 & 1.542 & 1.402 & 0.135 & 0.104 & 0.134 & 0.123 & -2.41 & 2.433 & 411 \\
\hline $26^{*}$ & 5238 & 10.536 & 0.872 & 1.624 & 1.784 & 0.969 & 0.963 & 0.966 & 0.965 & -2.22 & & \\
\hline 4 & 5529 & 8.896 & 1.622 & 1.573 & 1.357 & 0.121 & 0.107 & 0.072 & 0.101 & -2.79 & 1.603 & 624 \\
\hline 17 & 5612 & 8.215 & 0.954 & 1.057 & 1.253 & 0.356 & 0.380 & 0.232 & 0.316 & -2.56 & 0.386 & 2592 \\
\hline 28 & 5650 & 9.495 & 2.290 & 2.486 & 2.187 & 0.208 & 0.236 & 0.117 & 0.189 & -2.69 & 0.759 & 1318 \\
\hline 16 & 6067 & 9.244 & 0.955 & 1.192 & 1.336 & 0.209 & 0.203 & 0.214 & 0.209 & -2.32 & 0.625 & 1600 \\
\hline 3 & 6071 & 6.960 & 1.020 & 1.104 & 0.837 & 0.272 & 0.356 & 0.216 & 0.288 & -2.62 & 0.408 & 2451 \\
\hline 27 & 6686 & 9.088 & 1.391 & 2.445 & 2.350 & 0.145 & 0.230 & 0.196 & 0.198 & -2.27 & 0.606 & 1649 \\
\hline 59 & 8158 & 7.609 & 0.813 & 1.078 & 1.012 & 0.073 & 0.096 & 0.102 & 0.092 & -2.29 & 1.217 & 822 \\
\hline 61 & 8167 & 7.440 & 0.544 & 0.803 & 0.683 & 0.070 & 0.101 & 0.076 & 0.084 & -2.41 & 1.332 & 751 \\
\hline 15 & 8255 & 6.576 & 1.033 & 0.899 & 0.813 & 0.276 & 0.223 & 0.269 & 0.257 & -2.67 & 0.351 & 2849 \\
\hline 58 & 8536 & 8.364 & 0.916 & 1.031 & 0.846 & 0.175 & 0.143 & 0.109 & 0.143 & -2.73 & 0.702 & 1424 \\
\hline 60 & 8597 & 9.726 & 0.788 & 1.039 & 1.155 & 0.154 & 0.127 & 0.137 & 0.138 & -2.36 & 0.727 & 1376 \\
\hline 57 & 8607 & 7.202 & 0.619 & 0.607 & 0.549 & 0.094 & 0.116 & 0.049 & 0.088 & -2.72 & 1.210 & 827 \\
\hline 62 & 9131 & 8.342 & 0.715 & 0.890 & 0.790 & 0.084 & 0.094 & 0.133 & 0.104 & -2.23 & 0.944 & 1059 \\
\hline 66 & 9317 & 7.071 & 0.860 & 0.926 & 0.755 & 0.130 & 0.176 & 0.112 & 0.142 & -2.58 & 0.651 & 1536 \\
\hline 65 & 10058 & 8.380 & 0.868 & 1.148 & 0.987 & 0.280 & 0.335 & 0.285 & 0.303 & -2.45 & 0.229 & 4368 \\
\hline 56 & 10146 & 8.579 & 0.997 & 1.420 & 1.356 & 0.149 & 0.102 & 0.104 & 0.115 & -2.53 & 0.758 & 1319 \\
\hline 2 & 10268 & 10.800 & 2.014 & 1.977 & 1.632 & 0.162 & 0.076 & 0.084 & 0.109 & -3.06 & 0.796 & 1256 \\
\hline 63 & 10308 & 8.548 & 1.160 & 1.310 & 1.000 & 0.086 & 0.135 & 0.092 & 0.106 & -2.52 & 0.818 & 1223 \\
\hline 55 & 10412 & 7.022 & 0.882 & 1.025 & 0.743 & 0.066 & 0.088 & 0.084 & 0.080 & -2.47 & 1.108 & 903 \\
\hline 1 & 10457 & 14.634 & 5.307 & 3.385 & 1.764 & 0.142 & 0.175 & 0.082 & 0.143 & -3.01 & 0.574 & 1741 \\
\hline 64 & 10727 & 9.418 & 0.775 & 1.124 & 1.180 & 0.095 & 0.089 & 0.085 & 0.089 & -2.37 & 0.951 & 1052 \\
\hline
\end{tabular}

accord with those calculated separately from a modified Equation (7):

$$
\lambda=\frac{c_{\text {granite }}^{T \geq 0} \cdot T}{\left(1-c_{\text {granite }}^{T \geq 0}\right)},
$$

where $T$ in this case represents the transport length from the Vermilion Fault. In contrast to erosivity values, erosion length scales are not dependent on the initial $m$ estimate used, and appear to be a robust assessment of an intrinsic property of the glacial transport system.

Erosion length scale values calculated for locations beyond $8 \mathrm{~km}$ transport length have a mean value of $1500 \mathrm{~m}$ (Table 1 and Fig. 9), indicating that till composition is dominantly controlled by material derived from local bedrock. This value is consistent with the empirical observations of an apparent lack of far-travelled material in the till, and of high compositional variability and heterogeneity in tills overlying the greenstone belt.

\section{Conclusion}

The conceptual model of glacial erosion-entrainment and transport presented herein provides a convenient framework for analyzing tills and till-forming processes. Our model relates the spatial variability in indicator concentration in till sheets (expressed as a function of transport length from the indicator source) to rates of incorporation of mass into the glacial debris 


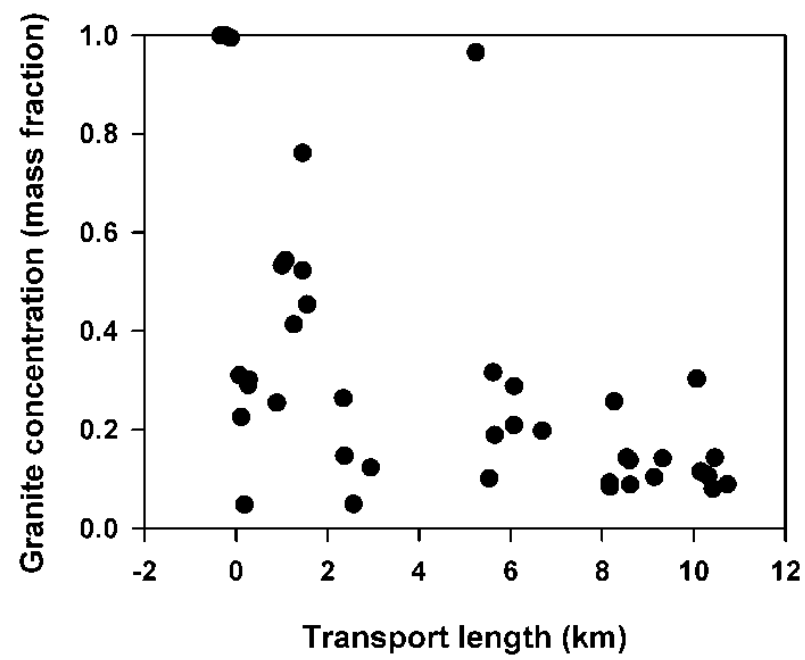

Fig. 6. Granitic concentration in the $2-16 \mathrm{~mm}$ fraction of tills overlying the Vermilion Greenstone Belt. Transport length calculated along flowline from Vermilion Fault.

load. This relationship is expressed in terms of the physically meaningful variables of erosivity $E$ and erosion length scale $\lambda$. We therefore confirm that changes in indicator concentration in a till sheet can be quantitatively linked to the physical processes of erosion, entrainment, transportation, and deposition acting at a glacier's bed.

The total indicator concentration in a till sheet $\left(c_{D I L}\right)$ is chiefly a function of erosivity $E$, a term describing the coupling between a glacier's bed and the glacially transported debris load. Erosivity is proportional to the erosion rate (Eqn. 2). Closely related to erosivity is the erosion length scale $\lambda$, describing influence of debris

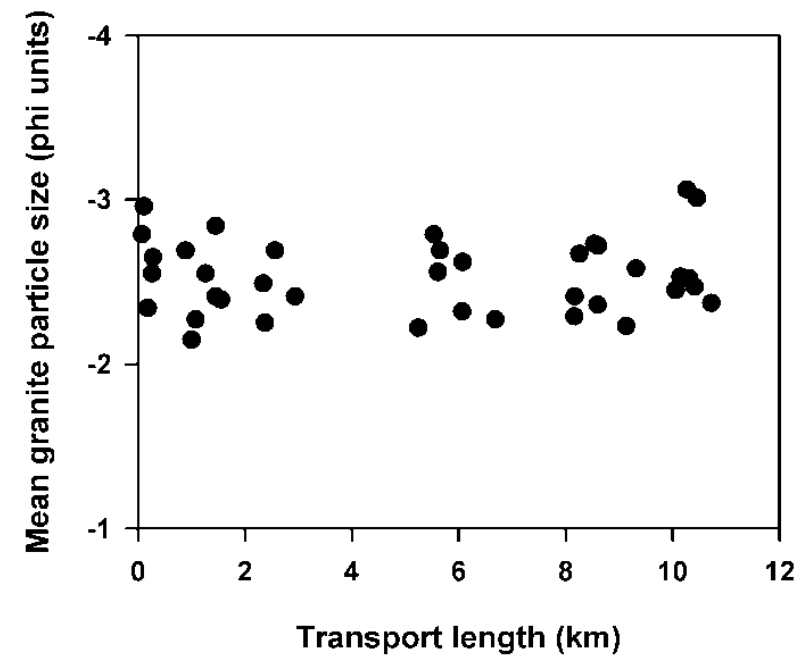

Fig. 7. Mean particle size of granitic clasts in $2-16 \mathrm{~mm}$ fraction of tills overlying the Vermilion Greenstone Belt.

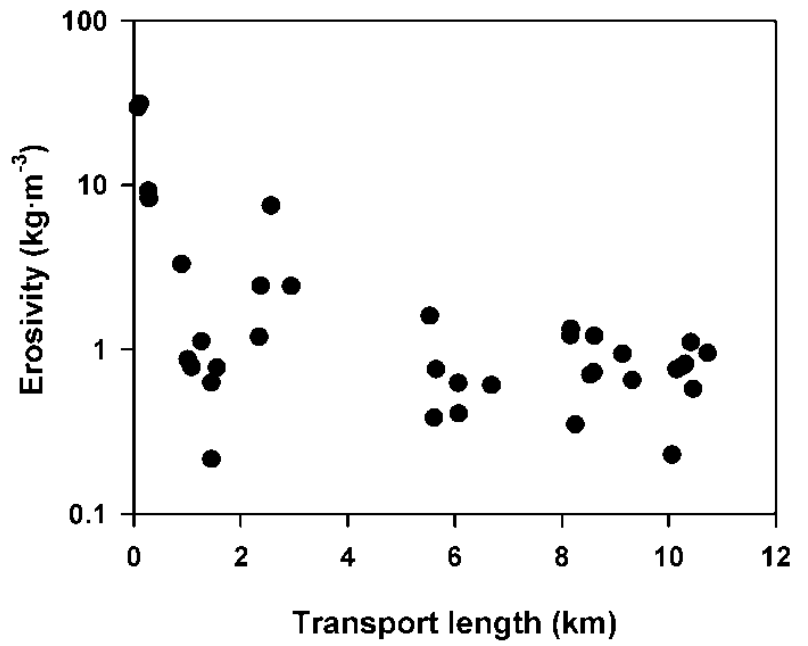

Fig. 8. Erosivity values for tills overlying the Vermilion Greenstone Belt. Each data point represents a unique solution for the mean erosivity over the flowline extending from the Vermilion Fault to the sample location.

carried by the glacier from up-ice of the indicator source on the generation and apparent down-ice persistence of an indicator dispersal train. Given spatially uniform erosivities, the maximum magnitude of indicator concentration and the apparent transport length of the indicator dispersal train are functions of the magnitude of the erosion length scale and the flowline length of the indicator outcrop (Eqn. 7).

Determination of indicator concentrations in terms of mass fraction permits quantification of the effects of comminution on the evolution of the debris load during transport. Comminution of indicator material in a

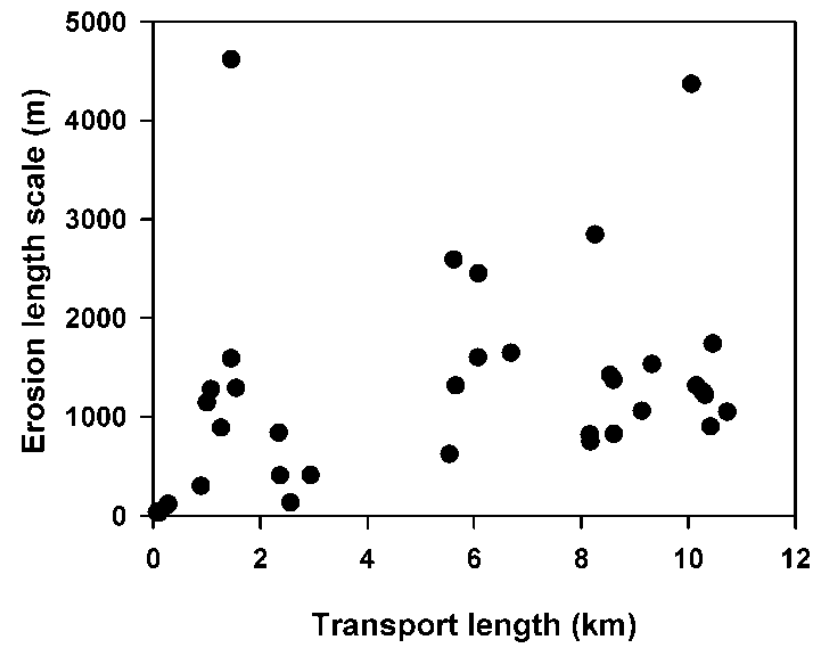

Fig. 9. Erosion length scale values for tills overlying the Vermilion Greenstone Belt. Each data point represents a unique solution for the erosion length scale over the flowline extending from the Vermilion Fault to the sample location. 
glacial system is analogous to a batch grinding particle comminution model (Eqn. 8). Adaptation of this framework offers the potential of elucidating the particular comminution processes (crushing, surface abrasion, etc.) operating in a glacial system, and quantifying the rates at which they act on the debris load.

Application of the conceptual framework to interpretation of indicator dispersal patterns in till overlying the Vermilion Greenstone Belt, Minnesota provides important insight into the nature, and rates, of glacial erosion operating in this sector of the LIS during its retreat. Results indicate that erosion, entrainment, and transport during retreat of the LIS over bedrock terrain operated at high rates for a relatively short time period over a spatially restricted area of the bed. In this respect, they apparently operated in a fashion fundamentally different than occurred farther to the southwest at the Last Glacial Maximum.

Our model describes indicator distribution in a till sheet produced by steady-state glacial erosion, entrainment, transportation, and deposition processes. In as much as these processes are unlikely to act in a strict steady-state fashion either spatially or temporally within a glacial system, we do not expect that our model will perfectly describe indicator distribution everywhere in every till sheet. However, the model does provide a template for investigating the role of precisely such spatial and temporal variations in glacial sediment transport and till generation.

Acknowledgements. - G. Miron is thanked for field assistance in support of this project. The work was initiated by a grant from the Minnesota Department of Natural Resources, Division of Minerals. We gratefully acknowledge R. Hooke for helpful and constructive comments on an earlier version of this manuscript. Finally, we thank S. Haldorsen, W. Shilts and J. Piotrowski (Editor) for thoughtful and constructive reviews of this manuscript.

\section{References}

Alley, R. B. 1991: Deforming bed origin for southern Laurentide till sheets? Journal of Glaciology 37, 67-76.

Alley, R. B., Cuffey, K. M., Evenson, E. B., Strasser, J. C., Lawson, D. E. \& Larson, G. J. 1997: How glaciers entrain and transport basal sediment: physical constraints. Quaternary Science Reviews 16, 1017-1038.

Boulton, G. S. 1996: Theory of glacial erosion, transport and deposition as a consequence of subglacial sediment deformation. Journal of Glaciology 42, 43-62.

Clark, P. U. 1994: Unstable behavior of the Laurentide ice sheet over deforming sediment and its implications for climate change. Quaternary Research 41, 19-25.

Drake, L. D. 1972: Mechanisms of clast attrition in basal till. Geological Society of America Bulletin 83, 2159-2166.

Dreimanis, A. 1989: Tills, their genetic terminology and classification. In Goldthwait, R. P. \& Matsch, C. L. (eds.): Genetic Classification of Glacigenic Deposits, 17-84. A. A. Balkema, Rotterdam.

Dreimanis, A. \& Vagners, U. J. 1971: Bimodal distribution of rock and mineral fragments in basal tills. In Goldthwait, R. P. (ed.): Till - A Symposium, 237-250. Ohio State University Press, Columbus.
Drewry, D. J. 1986: Glacial Geologic Processes. 276 pp. Edward Arnold, London.

Flint, R. F. 1971: Glacial and Quaternary Geology. 892 pp. Wiley, New York.

Gillberg, G. 1965: Till distribution and ice movements on the northern slopes of the south Swedish highlands. Geologiska Föreningens $i$ Stockholm Förhandlingar 86, 433-484.

Haldorsen, S. 1981: Grain-size distribution of subglacial till and its relation to subglacial crushing and abrasion. Boreas 10, 91-105.

Hallet, B., Hunter, L. \& Bogen, J. 1996: Rates of erosion and sediment evacuation by glaciers: a review of field data and their implications. Global and Planetary Change 12, 213-235.

Hicock, S. R. \& Dreimanis, A. 1992: Deformation till in the Great Lakes region; implications for rapid flow along the south-central margin of the Laurentide ice sheet. Canadian Journal of Earth Sciences 29, 1565-1579.

Holmes, C. D. 1960: Evolution of till-stone shapes, central New York. Geological Society of America Bulletin 71, 1645-1660.

Hooyer, T. S. \& Iverson, N. R. 2002: Flow mechanism of the Des Moines lobe of the Laurentide ice sheet. Journal of Glaciology 48, 575-586.

Horst, W. E. \& Freeh, E. J. 1970: Mathematical modeling applied to analysis and control of grinding circuits, Part 1: Development of comminution models. Society for Mining Metallurgy and Exploration of the American Institute of Mining, Metallurgical, and Petroleum Engineers (SME of AIME) Preprint 70-B-27.

Humlum, O. 1985: Changes in texture and fabric of particles in glacial traction with distance from source, Mýrdalsjökull, Iceland. Journal of Glaciology 31, 150-156.

Kjær, K. H. 1999: Mode of subglacial transport deduced from till properties, Mýrdalsjökull, Iceland. Sedimentary Geology 128, 271-292.

Klassen, R. A. 2001: A quaternary geological perspective on geochemical exploration in glaciated terrain. In McClenaghan, M. B., Bobrowsky, P. T., Hall, G. E. M. \& Cook, S. J. (eds.): Drift Exploration in Glaciated Terrain, 1-17. The Geological Society, London.

Knight, P. H. 1997: The basal ice layer of glaciers and ice sheets. Quaternary Science Reviews 16, 975-993.

Kujansuu, R. \& Saarnisto, M. (eds.) 1990: Glacial Indicator Tracing. 252 pp. A. A. Balkema, Rotterdam.

Lehr, J. D. \& Hobbs, H. C. 1992: Field trip guidebook for the glacial geology of the Laurentian Divide area, St. Louis and Lake Counties, Minnesota. Minnesota Geological Survey Guidebook Series 18.

McClenaghan, M. B., Thorleifson, L. H. \& DiLabio, R. N. W. 2000: Till geochemical and indicator mineral methods in mineral exploration. Ore Geology Reviews 16, 145-166.

McClenaghan, M. B., Bobrowsky, P. T., Hall, G. E. M. \& Cook, S. J. (eds.) 2001: Drift Exploration in Glaciated Terrain. 350 pp. The Geological Society, London.

Matsch, C. L. 1972: Quaternary geology of southwestern Minnesota. In Sims, P. K. \& Morey, G. B. (eds.): Geology of Minnesota: A Centennial Volume, 548-560. Minnesota Geological Survey, St. Paul.

Milthers, V. 1909: Scandinavian indicator boulders in the Quaternary deposits; extension and distribution. Danmarks Geologiske Undersøgelse Ser. 2, No. 23.

Peltoniemi, H. 1985: Till lithology and glacial transport in Kuhmo, eastern Finland. Boreas 14, 67-74.

Perttunen, M. 1977: The lithological relationship between till and bedrock in the region of Hämeenlinna, southern Finland. Geological Survey of Finland Bulletin 291, 68 pp.

Peterson, D. M. \& Jirsa, M. J. 1999: Bedrock geologic map and exploration data, western Vermilion District, St. Louis and Lake Counties, Minnesota. Minnesota Geological Survey Miscellaneous Map Series 98.

Piotrowski, J. A., Mickelson, D. M., Tulaczyk, S., Krzyszkowski, D. \& Junge, F. W. 2001: Were deforming subglacial beds beneath 
past ice sheets really widespread? Quaternary International 86 , 139-150.

Prest, V. K. \& Nielsen, E. 1987: The Laurentide Ice Sheet and longdistance transport. In Kujansuu, R. \& M. Saarnisto (eds.): INQUA Till Symposium, Finland 1985, 91-101. Geological Survey of Finland Special Paper 3.

Repo, R. 1957: Untersuchungen über die Bewegungen des Inlandeises in Nordkarelien. Bulletin de la Commission Géologique de Finlande 179, $178 \mathrm{pp}$

Robin, G. de Q. 1976: Is the basal ice of a temperate glacier at the pressure melting point? Journal of Glaciology 16, 183-196.

Sauramo, M. 1929: The Quaternary geology of Finland. Bulletin de la Commission Géologique de Finlande 86, $110 \mathrm{pp}$.

Sharp, M. \& Gomez, B. 1986: Processes of debris comminution in the glacial environment and implications for quartz sand-grain micromorphology. Sedimentary Geology 46, 33-47.
Shilts, W. W. 1976: Glacial till and mineral exploration. In Legget, R. F. (ed): Glacial Till: An Interdisciplinary Study, 205-224. Royal Society of Canada Special Publication 12.

Shilts, W. W. 1982: Glacial dispersal; principles and practical applications. Geoscience Canada 9, 42-47.

Shilts, W. W. 1993: Geological Survey of Canada's contributions to understanding the composition of glacial sediments. Canadian Journal of Earth Sciences 30, 333-353.

Sugden, D. E. \& John, B. S. 1976: Glaciers and Landscape: A Geomorphological Approach. 376 pp. Edward Arnold, London.

Thorleifson, L. H. \& Kristjansson, F. J. 1993: Quaternary geology and drift prospecting, Beardmore-Geraldton area, Ontario. Geological Survey of Canada Memoir 435, 146 pp.

Weertman, J. 1961: Mechanism for the formation of inner moraines near the edge of cold ice caps and ice sheets. Journal of Glaciology 3, 965-978. 